УДК 821.161.2-32.09:128

Свірська Ж. М.

кандидат педагогічних наук, дочент Криворізький педагогічний інститут ДВНЗ «Криворізький національний університет»

\title{
МОТИВИ СМЕРТІ У ХУДОЖНІЙ СТРУКТУРІ НОВЕЛ М. ХВИЛЬОВОГО
}

У статті проведено художній аналіз новел М. Хвильового. Головні герої перебувають у неіснуючому світі революиії, який водночас $\epsilon$ "країною мрій» $i$ «краӥною вибухів». Автор наділяє центральних персонажів «конфліктогенним» соиіальним статусом, звертає увагу на вагомі складові екзистенційної суперечності між прагненням до самореалізащії та відсутністю перспективи. 
На початку 20-х років вони переживають розчарування ц̆ депресію через неможливість знайти застосування свойм потенційним можливостям. Передусім, виокремлено проблематику: за втрат упевненості у світлому майбутті настроєва чи подієва смерть - невідворотний результат.

Ключові слова: «конфліктогенний» соціальний статус, екзистенційний вибір.

Статья посвящена художественному анализу новел Н. Хвилевого. Автор наделяет центральных персонажей конфликтным соииальным статусом, обращает внимание на составные экзистенциального выбора между стремлением к самореализации и отсутствием перспектив. В статье выделена проблематика: без уверенности в светлом будущем разочарование, депрессия или смерть - неизбежный результат.

Ключевые слова: конфликтный социальный статус, экзистенцииальный выбор.

This article provides an analysis of the novels of $M$. Khvylovyi. The main characters live in non-existent world of revolution, which is also the "Dreamland" and "country of explosions." The author gives to the main characters 'conflict-'social status, draws attention to the significant components of the existential contradiction between the desire for self-fulfillment and lack of perspective. In the early 20 s they experience frustration and depression due to inability to be used to its potential. First of all, determined problems: emotional or physical death is the inescapable result of losing the confidence in the bright future.

Key words: 'conflict-' social status and existential contradiction

Постать Миколи Хвильового, власне його художня та публіцистична спадщина в сучасному літературознавстві $€$ об'єктом постійної уваги. На сьогодні маємо розлогу палітру літературознавчих інтерпретацій його творчості. У дослідженнях значну увагу приділено стильовій своєрідності прози, щзо стали предметом вивчення у працях В. Агеєвої, Т. Гундорової, Ю. Безхутрого та ін. Важливим $\epsilon$ розкриття еволюції суспільнополітичних поглядів М. Хвильового, його розуміння перспектив розвитку 
української літератури та вимог щодо іiі неодмінної «європеїзації» (В. Мельник, В. Шевчук та ін.). Дослідники торкаються проблеми бінаризму як неодмінної властивості творчого мислення митця, світовідчуття персонажів, відбиття суперечливих особистісних і суспільних настроїв людини 20-х років XX сторіччя (В. Сиротинко, М. Руденко та ін.). Філософії «Я» в художній концепції письменника, духовним драмам персонажів новел присвячені розвідки К. Дуба, I. Ручки та ін. Грунтовно висвітлено психопатичний дискурс (С. Павличко). Численними є статті, де приділено увагу парадигмі невротичного героя у наративі повістей, дисгармонійному як аксіологічному аспекту поетики, експресіоністичним тенденціям прозових творів.

Однак художня танатологія - нова сфера досліджень сучасного літературознавства. Поза увагою ще залишаються танатологічні мотиви, гендерні аспекти творчої концепції, що $\epsilon$ перепоною на шляху до осягнення індивідуального стилю, авторської позиції. Вибір новел зумовлений яскраво вираженою психологією персонажів, що проявляється через константу «смерть».

Мета статті полягає в тому, щоб шляхом аналізу й зіставлення новел виявити духовні ціннісні орієнтації персонажів, окреслити причини та наслідки краху омріяних ідеалів та реакцію на почуття «зайвості» у пореволюційні часи.

Щодо вивчення концепту «смерть» в індивідуальному стилі митця, зосібна у художній структурі новел, варто обрати психоаналітичну інтерпретацію. Для iї тлумачення орієнтуємося на концепцію М. Моклиці, де на основі психологічних типів К. Г. Юнга розглянуто естетику модерну.

Початок XX століття став переламним періодом не тільки в суспільстві, а й у розвитку літератури, що пориває з традицією та шукає інші шляхи відображення дійсності. Результатом цього пошуку стають новий тип жінки і чоловіка у новій системі соціальних відносин, нові моделі людських стосунків. Цю тезу вповні ілюструє творчість М. Хвильового, який руйнує усталені класичні варіанти: пасивна жінка - 
активний чоловік. Через новели наскрізне проходить концепт «смерть». Письменник послідовно розгортає трагічний мотив перебудови світу за жорстокими правилами, до яких людина виявляється не готовою. Автор уміщує персонажів у однакові умови: втрати ідеологічних ілюзій, розчарованості у здійсненому, відчуття зайвості на «святі переможців», сталого тиску оточення. А відтак - психологічна напруга, депресія, пристрасне видивляння в смерть.

Герої новел «Юрко», «Заулок» знають, що минуле залишилося в минулому - «назад нема вороття». Слід зробити вибір: або, або («дух творчості, дух руйнування)». Треба обрати: змиритися чи піти з життя. Змиритися для революціонерів означатиме відмову від ідей, мрій, того, за що боролися, вмирали, вбивали, чому присвятили себе і чого ніколи не буде у збудованому суспільстві.

M. Хвильовий одним із перших суб'єктивно й пристрасно почав осмислювати проблему смерті в українській літературі періоду державотворення. 3 усіх різновидів смерті увагу він концентрує на суїциді. Започатковується мотив у перших абзацах: у заулку - «сивий присмерк», дзвін б’є «глухо й вогко».

Мар'яна, «року 1917», по-дитячому повірила у дієву силу революції. Покинувши школу, непересічну енергію, бажання підкорила служінню ідеї. Вона бачила себе незламним поборником правди й лише правди, відкинувши те, що завадить цьому. Історію характеру персонажа подає репліка «к чорту!». Активні пошуки свого місця у світі приводить дівчину до чека. «I сказав тоді Аркадій Андрійович. - Мар'янко! Що ти робиш? I сказала тоді Степанида Львівна: - Мар'янко! Що ти робиш?? А потім погодились: «така Божа воля» [Хвильовий 1995 : 203]. Саме очима Мар'яни бачимо значну частину подій в час, коли «... женщзини револющіï пішли плодити дітей». Вона не здатна прийняти дійсність, відмовитися від ідеалів, які активно пропагувала, у які свято вірила, забути усе. Як і Юрко, дівчина відчуває як «до серия підкотилась злість». Для Мар'яни виродження розтягується на «тисячі років». «Безпартійна комуністка»не 
пам'ятає, за що іiі якось непомітно вигнали 3 партії, «проте ц̧е єрунда». Переможцями виявилися ті, проти кого, на іiі думку, революція боролася. Героїня «Заулку» подумки повертається в ситуацію «виру». «Пам'ятаєи? - стоять ешелони. Їдемо в дикі замріяні степи, де чекає тривога, невідомість, де ціле провалля жури й радості... [Хвильовий 1995 : 203]. За словами Мар'яни: «Тоді не було порожнечі...» [Хвильовий 1995 : 203]. Зараз - «у мені осінь». «Порожнеча гамарила кожний нерв ї icmoти» - вже немає «Секім-башка!» [Хвильовий 1995 : 203]. Вчорашня чекістка у нових обставинах не здатна знайти застосування «творчим» силам. Що діймає жінку?

По-перше, для одержимої маніакальною ідеєю справедливості, «...найкраще слово на землі: «че-ка». Вона плекає віру: «воскресне велике слово - «че-ка!». Тоді воскресне бірюзовий потік людського натхнення й степова тривога» [Хвильовий 1995 : 204].

По-друге, «два чудових російських слова» «сєвєр» і «грусть» не перекладаються. «Сєвєр» і «Грусть» для чекіста не мають відповідників.

Утрата ідеологічних ілюзій - втрата сенсу іiі буття. Молода жінка, у часи, за яких нехається смерть, знецінено життя, не бачить виходу, не шукає опори в сім'ї, як Юрко. Бути матір'ю - органічна сутність жінки. Але «небагато», - серед них Мар'яна, - «не пімли плодити дітей» [Хвильовий 1995 : 110]. Думка, що варто жити за будь-яких умов, відкидається. Відтак материнство приноситься на офіру доктрині комуни.

Важливе місце в новелі посідає еротичний аспект. У стосунках із чоловіками Мар'яна хоче «залити себе дурманом» до «солодкоӥ нестями». «Ніжна жінка й хороша хазяйка» Степанида Львівна, начебто, переймається тим, що донька не ночує вдома, адже «про Мар'яну говорять!». У фабулі «Заулку» на перше місце виходять патологічні вияви. У Хвильового маємо намагання пояснити причини таких змін - у добу нетипова поведінка жінок, що цілком суперечить принципам моралі, стає закономірною. Це один із ракурсів мотиву смерті, який акумулює чимало питань проблемного характеру, зокрема морального вибору. Яскравий художник описує протиприродні жіночому єству 
стосунки, 3 першим-ліпшим партнером, вчинки, що не були необдуманими. Психологічне зміщення призводить до деградації особистості, яка втратила грунт, що забезпечувався силою традицій, моралі. Як виклик, Мар'яна «вийняла з чулка пачку кредиток $i$ з силою кинула їх у куток» [Хвильовий 1995 : 203]. Навіть для неї дико те, що вона продала своє тіло не будь-кому, з огидою згадує вакханалію в «грандОтелі». Ця ненормальність іде від тієї ж відсутності внутрішньої стабільності. Набувають гіперболізованого значення згадки про «звіряче обличчя гладкого типа, $i$ гнійні нарости на його животі» [Хвильовий 1995 : 203]. Жіночий блуд і розпуста несуть у собі смисли, аналогічні смерті. Звернімо увагу на образ «порожніх фосфоритів», що загорілися в очах жінки. Мотив смерті актуалізується буквально в кожному подальшому подієвому штриху новели: «у вікно бились краплі мжички...». I хоч альтернативи немає, самогубство все ж проблемне. Мар'яна вагається, нервово перебираючи складки на спідниці, бродить кімнатами. Бредуть години внутрішньої боротьби. Для розуміння подальших дій персонажа автор вводить невласне пряму мову: «з жахом подумала: Прощзай?». Молодість ж бо не хоче вмирати! Але «тоді» вона не раз наражала себе на небезпеку, жертвувала собою заради наближення світлого майбутнього і без вагань ладна була померти. «Тепер» зневірена, самотня дівчина приречена на загибель. Реакція на смерть провокує глибинне усвідомлення індивідуального смислу життя. Емоційна насиченість рефлексій спричинила пошук відповіді на питання: «Що - ие суїиид? безпорадність? Сила волі? Слабкість? Не знаєте?» [Хвильовий 1995 : 204]. Сдине, що вона знає, це те, що їй забракне духу, але переконує себе у правильності здійсненого екзистенційного вибору: «Це найкращиий спосіб проявити силу своєї волі. Правда?» [Хвильовий 1995 : 204]. Те, що вибір демонструє цілісність натури, - безперечно: «Я тобі писала, щуо хочу покінчити з життям. I от я рімила.. <..> P. S. Через годину повішусь. Прощзай». [Хвильовий 1995 : 204]. Однозначно прийняте рішення є 
незмінним: «Так роблять чекісти минулого». Далі «дороги» немає. [Хвильовий 1995 : 203-204].

Звернімо увагу на слово «єрунда», яке належить героїні. Либонь, ним Мар'яна намагається відігнати страх: «Єрунда, треба кінчати!». Народна ритуальна культура позначає самовбивцю як істоту позакалендарну, позациклічну. Проте в атеїстичному суспільстві страх самовбивства втрачений, а нагадати про гріховність самогубства нікому.

Слово не повинно розходитися з ділом. Це не позірна істерика, в яку впав Юрко при написанні листа. Це обміркований, виважений крок. У цьому Мар'яна сильніша за Юрка. Цікаво, що чоловік надіявся на те, що саме жінка врятує від «тиші» та його «не можу».

На кого ж опертися Мар'яні? Мабуть, на Гамбарського, перед очима якого вона стоїть завжди, який ऑї згадує «фіалково». Та інтереси «червоного професора» замкнуті у мікрокосм власної персони, а точніше у примарну мрію пишатися своїм іменем на афішах. Письменник показує, як відбувається перерозподіл ролі між жінкою та чоловіком на психологічному рівні. Леонід Гамбарський дивиться «прибито, перелякано». Він жахається. І знову «прибито й перелякано» дивиться. Цей погляд дає знак: «Далі не можна. Треба кінчати!». Закоханий чоловік, «блідий $i$ розгублений», у вирішальний момент не знаходить слів, щоб розрадити Мар'яну, яка «дивилась сухими фосфоритами. Треба повіситися... Негайно... зараз... [Хвильовий 1995 : 206]. Марно сподіватися, що «липовий» професор може Мар'яні дати відповіді на питання «щуо таке безпорадність? Що сила волі?» [Хвильовий 1995 : 206]. «Чванлива дівчина», а водночас слабка і безпорадна, якою Мар'яна стає на мить, прийшла до чоловіка за поміччю «спитати... прохати...». Жінка йде до чоловіка, як гаранта сили розуму, яким він має бути від природи. Відтак не лише не отримує надійної підтримки, а усвідомлює, наскільки цей нікчема слабший від неї. Це випливає з репліки типу: «Тягуче проходили хвилини напруженої мовчанки». Виписані сцени справляють враження ні 3 ким не розділеного страждання. Надіятися ні на кого, ніхто не врятує, 
ослаблений потяг до життя продукує потяг до смерті: «Так! Треба кінчати... Так! Скоріше!..» [Хвильовий 1995 : 206].

Отже, «пишна женщина», яку скалічила кров і смерть, не бореться. Два настрої сплітаються в атмосфері тривоги: «Ішла глибока сіра осінь по сірих заулках республіки» і «Ми ковалі, ми ковалі, Куєм ми щзастя на землі» [Хвильовий 1995 : 203]. Прикінцевий епізод начебто має поставити остаточну крапку у глухому роздоріжжі: «Куди? Через дорогу, до Глухайської вулиці...» [Хвильовий 1995 : 209]. Але самогубства, принаймні в ніч, яку описує письменник, не відбувається. Щоправда, судячи з фрази: «А щзоб не було повороту, сьогодні вночі віддалась сифілітикові» [Хвильовий 1995 : 206], вона врешті збереться на силі, щоб піти у засвіти. Невід'ємною частиною творення небуття є поява носія смерті. Промовиста художня деталь «віжки» підказує, що жінка неминуче обере смерть як евентуальний вихід із ситуації «глухості».

Як бачимо, герої новел «Юрко» і «Заулок» жалкують за жагою до вибухів, до вбивств, до самозречених революційних боїв. Жаскі зрощення лиходійства та тривоги, крові та смерті стають невід'ємними складовими «муралів» революції. У їхній психології вкорінюється мізантропія. І Юрко, i Мар'яна не знаходять однодумців поруч. Не маючи розуміння серед близьких, гризоти, що точать їх, виливають товаришам минулого. Свої пристрасні монологи Мар'яна адресує до далекого російського краю, невідомому нам «иилому другу». Схвильований Юрко теж «довго, надхненно» пише комусь листа. Попри те, що останні їх здебільше не зрозуміють, і не підтримають, їм нікому це сказати - вони чужі серед свого оточення. Оце «не можу»- «жити», «боротися», «змиритися», «нічого змінити» - $€$ свідченням психічної деградації. На грунті духовного вакууму виникає почуття абсолютної зайвості, викликане відірваністю від життя, що підсилюються спогадами про часи, коли вони вершили долі інших, стояли в рядах тих, хто чітко знав до чого прагнуть мільйони людей. 
Як свідчить художня проза, М. Хвильовий натиснув на больову точку своєї епохи. Художня інтерпретація мотиву смерті реалізується автором у модель світобудови, провідною ознакою якої $\epsilon$ відчуття

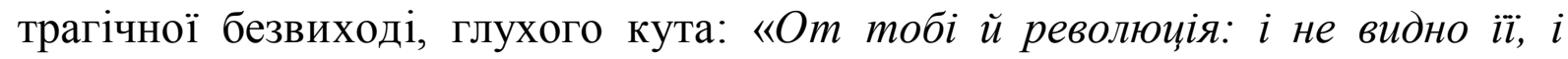
видно ї. Як ота благодать з неба: щось, десь, а в руки не візьмеш...» [Хвильовий 1995 : 211]. Знецінення вартості життя у ХХ столітті пов'язане 3 репресивними механізмами. У підтексті новел «Юрко» $\mathrm{i}$ «Заулок» наявний футуристичний прогноз - «як почнеш шукати правди, то, гляди, $i$ залізеш у кривду» [Хвильовий 1995 : 211]. Загроза потрапити під вплив агітаційних міфів для втілення примарного «царства справедливості» нависає повсякчас. Неусвідомлена «манія величі» відкриває дорогу новим злочинам. Сучасне суспільство характеризується ослабленим переживанням смерті, а символи насильства та індустрія образів знищення людини спотворюють свідомість покоління перших десятиліть XXI ст. Ймовірно, що подальший перехід від руйнівної діяльності до творчої для багатьох чоловіків і жінок стане неможливим.

\section{БІБЛІОГРАФІЯ}

Моклиця 2002 - Моклиця М. В. Модернізм як структура: Філософія. Психологія. Поетика : монографія / Марія Василівна Моклиця. - 2-е вид., доповн. і переробл. - Луцьк : РВВ "Вежа", 2002. - 389 с.

Павличко 2002 - Павличко С. Д. Психопатичний дискурс: Микола Хвильовий / Соломія Дмитрівна Павличко // Теорія літератури. - К. : Основи, 2002. -679 c.

Хвильовий 1995 - Хвильовий М. Новели. Оповідання. «Повість про санаторійну зону». «Вальдшнепи». Поетичні твори. Памфлети / М. Хвильовий. К. : Наукова думка, 1995. - 815 с.

Юнг 1986 - Юнг К. Г. Об отношении аналитической психологии к поэтико-художественному творчеству / Карл Густав Юнг // Зарубежная эстетика и теория литературы ХІХ-ХХ вв. - М., 1986. 